\title{
The Development of Urban Quality of Life Spatial Model using Geographic Information System (GIS) in Kuala Terengganu, Malaysia
}

\author{
Mohd Khairul Amri Kamarudin ${ }^{1,2^{*}}$, Lokman Abd Rahman², Mahadzirah Mohamad3, Wan Abdul Aziz Wan Mohd Amin, \\ Noorjima Abd Wahab², Mohd Ekhwan Toriman 4 , Roslan Umar ${ }^{2}$ and Siti Nor Aisyah Md Bati² \\ ${ }^{1}$ Faculty of Applied Social Sciences (FSSG), Universiti Sultan Zainal Abidin, Gong Badak Campus, \\ 21300 Kuala Nerus, Terengganu Darul Iman, Malaysia \\ ${ }^{2}$ East Coast Environmental Research Institute (ESERI), Universiti Sultan Zainal Abidin, Gong \\ Badak Campus, 21300 Kuala Nerus, Malaysia Selangor, Malaysia \\ ${ }^{3}$ Faculty of Economics \& Management Sciences, Universiti Sultan Zainal Abidin, Gong Badak \\ Campus, 21300 Kuala Nerus, Malaysia Selangor, Malaysia \\ ${ }^{4}$ Faculty of Social Sciences and Humanities, Universiti Kebangsaan Malaysia, 43600, Bangi,
}

Selangor, Malaysia

\begin{abstract}
The urbanisation process cause changes to the physical and non-physical environment to developing a town and Urban Quality of Life (UQoL). Kuala Terengganu is experiencing rapid urbanisation process over the past three decades. The main objective of this study to build the spatial model based on Geographic Information System (GIS) in the determination of UQoL in Kuala Terengganu, Malaysia. A total of 115 sampling location have chosen based on the current status of research UQoL in the study area. The method used includes the main stages of data analysis and processing of data mean score for each domain scores were analysed using GIS. The mean social domain, physical domain and access domain have been analysed through the technique of auto Inverse Distance Weighting (IDW-GIS). The correlation and regression methods were used to examine the relationship of urbanisation of research location and UQoL. The results showed the current status UQoL for the physical domain is in Class 2 with 78.92\%, social domain is in Class 2, 77.61\% and in Class 2 domain access, 95.01\%. Based on the findings of these domains, a synthetic UQoL space model was produced. Overall, the current status of UQoL in the study area in Class 3 with $63.92 \%$. The resulting space model based on spatial data sources from the year 2009 (land-use) and 2013 (satellite images) show that the area is in the south of Kuala Terengganu have a quality of life is better because of the proximity of the city centre and good infrastructure.
\end{abstract}

Keywords: Geographic Information System (GIS); spatial model; Inverse Distance Weighting (IDW); Urban Quality of Life (UQoL); Kuala Terengganu

\section{INTRODUCTION}

The urbanisation process changes the physical and nonphysical environments of a city. It involves urban' space organizations affecting the quality of life of the communities (Halvarg \& Henrik, 2013; Chiara et al., 2010; Azahan, 2009). According to Sigit (2012), urbanisation will usually affect the
Urban Quality of Life (UQoL). It may give negative impacts on UQoL including the environmental issues, land use deterioration, agricultural activities and land market speculation (Huang et al., 2009; Brueckner \& Largely, 2008; Fahy \& Cinnéide, 2008; Bibiana et al., 2006). The increasing of traffic problems and demand of fuel contributed to air pollution, disease spreading and losing of green areas

*Corresponding author's e-mail: mkhairulamri@unisza.edu.my 
(Kamarudin et al., 2015; Jean et al., 2008; Sturm \& Cohen, 2004).

Habibia \& Asadib (2011) said the urbanisation process give a positive impact on the quality of urban life such as the urbanisation increase the opportunities for population access for better infrastructure, domestic needed, education and employment. According to $\mathrm{Wu}$, (2006), the development of urbanisation increasing the economic level and job opportunities to increase the income (Cohen, 2006; Yuan, 2006). Kuala Terengganu District, Terengganu, Malaysia has an area of 60,528 .60 hectares which is supervised under the administration of the Kuala Terengganu City Council (Majlis Bandaraya Kuala Terengganu) (MBKT). Kuala Terengganu District is the study area for the spatial modelling research using Geographic Information System (GIS) to determine the UQoL (Figure 1). The urbanisation process in Kuala Terengganu from the trade activities in Kuala Terengganu city. After the 1970s, the process of urbanisation in this area grew rapidly after the industrialization development especially from petroleum industrialization at the east coast of Terengganu.
The urbanisation process in Kuala Terengganu proved from the increasing of resident's number from 359,700 in 2008 to 536,500 in 2020 with the growth rate of 3.3 per cent and in 2010 the data increasing to 1.40 million (Department of Statistics Malaysia, 2020; Kuala Terengganu District Local Plan, 2008). The urbanisation development can also be valued from the land-use changes around the district areas in Terengganu. The land-use changes increase to $21.13 \%$ from 2009 until 2013. Based on the Department of Town and Country Development (Jabatan Pembangunan Bandar dan Desa), Kuala Terengganu (2008) and the Kuala Terengganu District Local Plan (2008), on 1973 there are 9.70 per cent of built-up areas in Kuala Terengganu and increased by 15.29 per cent in 1980 and increased by 45.02 per cent in 1997 , 49.60 per cent in 2003, 51.3 per cent in 2009 and 53.5 per cent in 2013 (Department of Statistics Malaysia, 2020; Jabatan Perangkaan Malaysia, 2014). This increasing showed the process of urbanisation that has affected the UQoL level in the area (Figure 2).

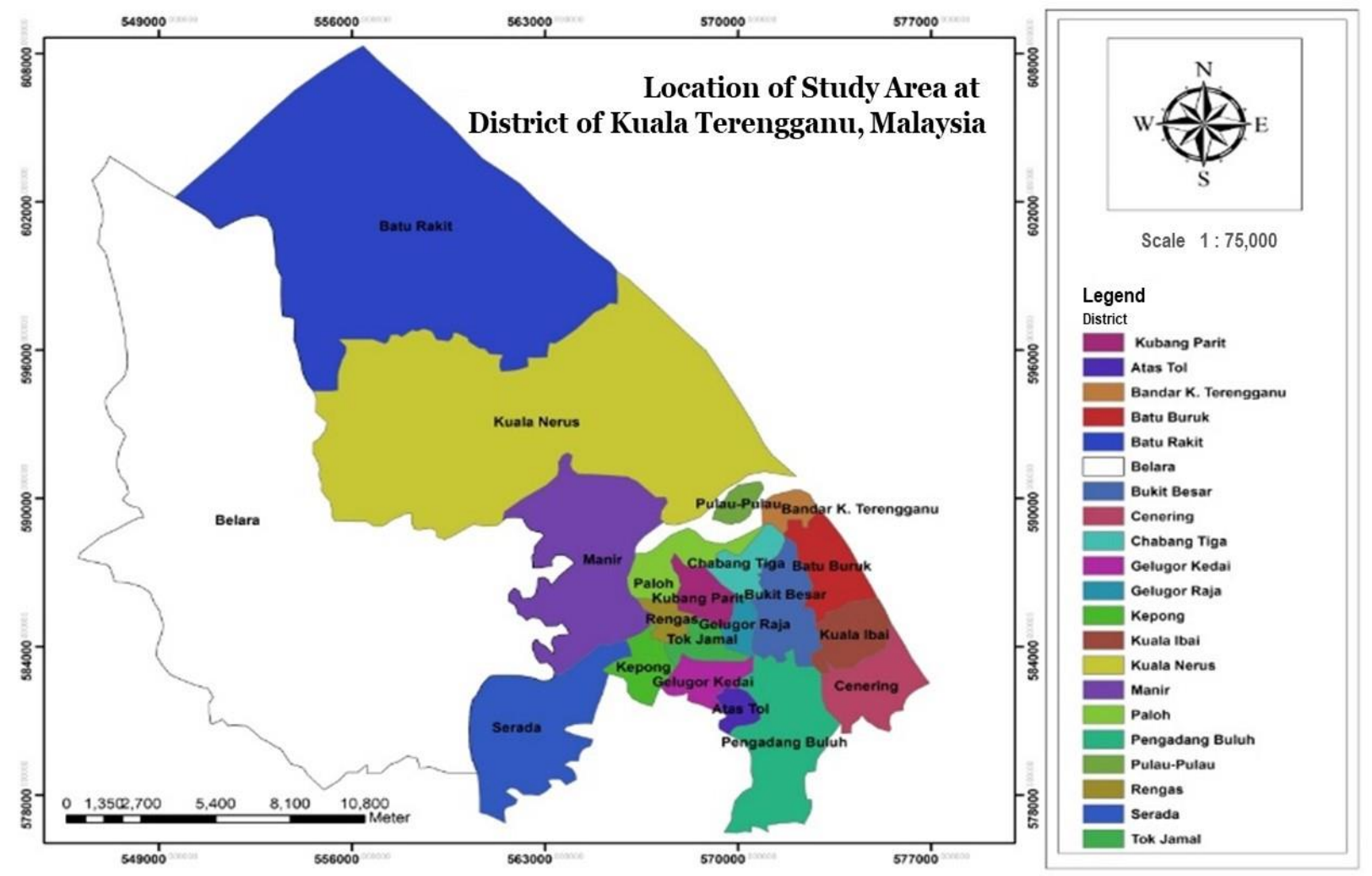

Figure 1. Location of Study Area at District of Kuala Terengganu, Malaysia

Based on the GIS applications in UQoL classification using Inverse Distance Weight (IDW) technique to create the spatial model of UQoL which are $17.9 \%$ of the geographic space as lowest, $67.6 \%$ moderate and $14.5 \%$ satisfied using 
the physical domain, social and economic but it is very poorly implemented. The measurement method of UQoL and urbanisation level from previous studies are which are more open without involved a space perspective. This situation makes it difficult to analysed and develop the quality of life because the influence of domain indicators on the UQoL level varies according to space. Hence, the using of GIS method in the development of spatial modelling of quality of life determination very accurate and expected solved this problem (Mohamad et al., 2018; Reap et al., 2008; Pourebrahim et al., 2011; Hiloidhari et al., 2017).

\section{STUDY AREA AND RESEARCH METHODOLOGY}

\section{A. Study Area}

Kuala Terengganu was selected as the study area which covered 10,340.94 hectares (103.41 km²). Kuala Terengganu as a centre of Terengganu state. Kuala Terengganu as the state's administrative centre, business and service centre. Before 1947, there are nine districts in the Terengganu States such as Kemaman, Kemasik, Paka, Dungun, Marang, Hulu Terengganu, Besut, Setiu and Kuala Terengganu (Wahab et al., 2019). However, in 1985, there are only seven districts when Paka and Kerteh combined as Kemaman. Kuala Terengganu located at longitude 103.14800o E and latitude 5.329180 N. Kuala Terengganu where continuous growth based on the increase of population and development residential areas (Figure 2).

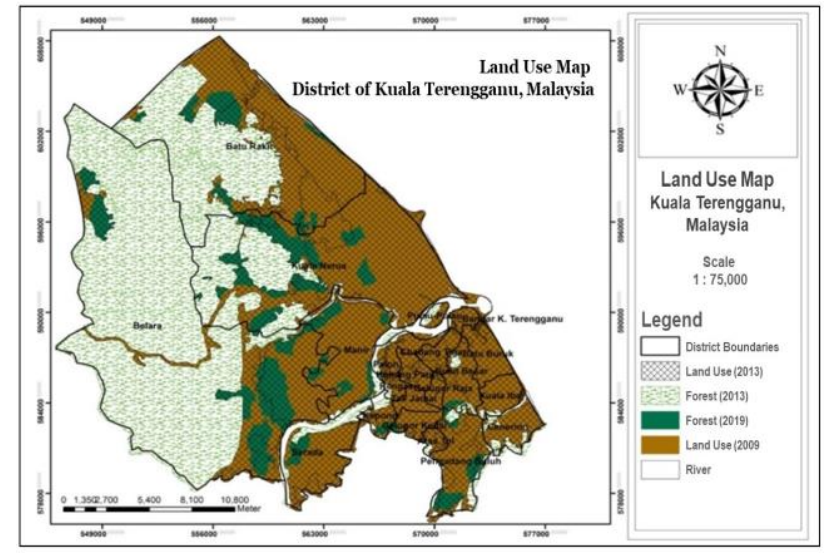

Figure 2. The land-use changes in the study area from 2009 until 2013, Kuala Terengganu, Terengganu, Malaysia

\section{B. Sampling Method}

In this study, 115 sampling centres were selected based on residential areas around Kuala Terengganu District to represent the overall study (Figure 3). The sample selection used simple random sampling technique. The population divided into several sampling units, where the required number of units is randomly selected from the population, so each unit of the population has the same opportunities.

384 respondents were selected based on the sampling selection formula based on a $5 \%$ sampling error (significance level ( $\alpha$ ) - .05) with a 95\% confidence level. The distribution of the respondents followed the weighting of the percentage according to the Mukim in the district of Kuala Terengganu. Besides that, this study used the subjective dimensions such as the measurement of five levels of Likert Scale which are classified between very satisfying until very dissatisfied. The list of survey questions used in this research based on landuse the Malaysian Economic Planning Unit (2010). These questions followed the Malaysia City Quality of Life standards based on three main domains such as social domain, physical domain and access domain with 45 indicators.

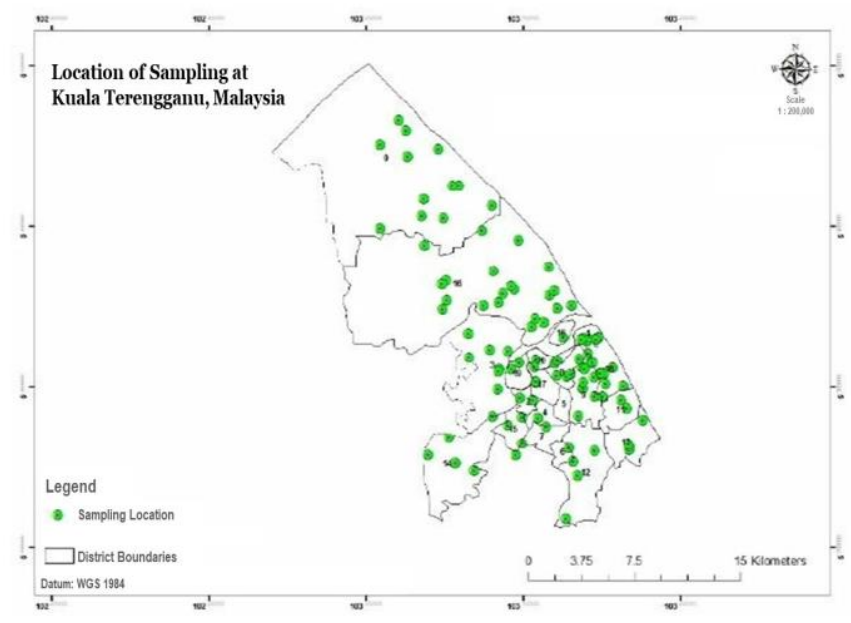

Figure 3. Sampling Location at Kuala Terengganu, Terengganu

\section{Geographical Information System (GIS)}

The data collected were processed using SPSS V21 software. The Mean values by domains and Mukim as basic data requirements for the formation of the database to build the spatial model using GIS. The urbanisation changes analysis in Kuala Terengganu District is carried out to identify the level of urban development around study areas. This analysis 
used the satellite image data; quick look Spot-5 (271/339, 272/240 and 271/340) Pansharp Supermode All Bands on 23/o9/2013, 28/o8/2013 and 06/08/2013 with a resolution of $2.5 \mathrm{~m}$, from the Agency Remote Sensing Malaysia (ARSM) (Figure 4).
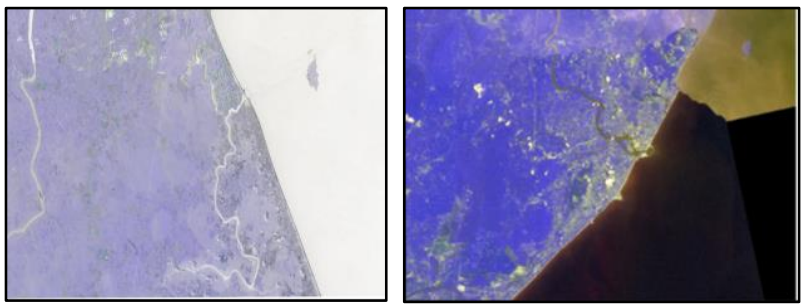

Figure 4. The data of the satellite image of Kuala Terengganu, Malaysia

This data is analysed to represent the urbanisation level at Kuala Terengganu in 2013 and then it's compared using GIS overlapping process with land use data obtained from Jabatan Pembangunan Bandar dan Desa (JPBD) Kuala Lumpur, 2009. All maps obtained will be geo-referent process coordinated using Projection: Kertau_RSO_Malaya_Meters. The mean score values based on data collected from the survey were interpolated using Inverse Distance Weighting (IDW) correlation technique to generate UQoL spatial model. The IDW interpolation is mathematical (deterministic) assuming closer values are more related than further values with its function. IDW will be interpolation the estimates unknown values based on spatial. To estimate the point in between, draw a dotted line to the $\mathrm{x}$-axis and then to the $\mathrm{y}$-axis. A good estimate of the blue point is 0.5 and 0.5 and just did a linear interpolation. Interpolation in GIS works the same. Take known points, create a surface by estimating unknown ones (Kamarudin et al., 2019; 2018; 2017; Wahab et al., 2017; Ghurah et al., 2018). This spatial model based on the scaling pattern of the mean score values which classified as physical domain, social domain, access domain and synthetic UQoL score for Kuala Terengganu District.

\section{Spatial Domain Model}

The spatial domain models used in this study such as the Physical Domain Spatial Models, Social Domain Spatial Models and Access Domain Spatial Models to determine the factors and the relationship between UQoL status and land use activities in Kuala Terengganu District. Besides that, the correlation between UQoL status and study areas distance from the city centre. The Physical Spatial Domain Model focused on determining the UQoL mean score values based on the transformation process of physical factors. While the Social Spatial Model focuses on the impact of social factors in achieving various strategies in the welfare of society. Then, the Spatial Access Model to determine the level of quality of urban living in the study areas based on accessibility factors in communication and technology systems (Pick \& Azari, 2008; Doi \& Nakanishi, 2008; Lotfi \& Koohsari, 2009). The Spatial Model of Synthetic is the combination of the three spatial domain models based on the pattern of scaling data of mean scores values according to the physical domain, social domain and access domain in Kuala Terengganu District.

\section{RESULT AND DISCUSSION}

\section{A. Physical Domain Spatial Model}

The spatial model showed the pattern of the mean values of the physical domain and UQoL in Kuala Terengganu. Based on Table 1 and Figure 5, the minimum mean score value is 1.47 to 2.14 classified as Class 1 . The areas are covered with the 3 brightest colours representing the southern areas of Kuala Terengganu which are Chendering, Kuala Ibai, Kuala Terengganu (City), Bukit Besar and Chabang Tiga. Then, Class 2 (moderate UQoL level) with minimum mean score value between 2.16 to 2.84 which representing central areas from Serada, Manir, Gong Badak and Kuala Nerus areas to Besut District. Besides that, Class 3 (lowest UQoL level) with minimum mean values between 2.84 to 3.53 . The areas covered with 3 darkest colour stages covered from the North Kuala Terengganu, Batu Rakit to Hulu Terengganu and Lake Kenyir. Generally, 90\% of the UQoL physical domain area in the southern part of the study is in class 1 . Whereas $80 \%$ north of the study area is in class 2 except for Mukim Batu Rakit with almost $20 \%$ of the area is in ranking 3 .

Based on Figure 6, the highest mean value of the physical domain was in Class 2, 78.92\% and Class 1 as 19.92\%. Then, the lowest mean value of physical domain was in Class 3 at $1.154 \%$. This result showed the physical development factors more developed in the central areas of Kuala Terengganu District compare in the north of Kuala Terengganu. This gives a positive impact on the level of UQoL among communities in 
the aspect of urban structures, morphology, population populations and the relationship between residents and the environment. The growth of physical development around the central and southern areas of Kuala Terengganu such as government service facilities, government buildings and more systematic urban development arrangements (Meyer \& Turner, 1992; Becker et al., 1999; Cohen, 2004). Also, the increase of population densities and quantities of residential areas around central areas of Kuala Terengganu such as Kuala Nerus, Gong Badak, Manir and Belara caused by the development a few of educational centres like Universiti Malaysia Terengganu (UMT), Universiti Sultan Zainal Abidin (UniSZA) and others educational institutes. Besides that, there is the development of industrial areas such as the Gong Badak industrial area.

Table 1. The mean value of Physical Domain Spatial Models and Urban Quality of Life (UQoL) Class in Kuala Terengganu, Terengganu, Malaysia

\begin{tabular}{cc}
\hline $\begin{array}{c}\text { Mean value of Physical } \\
\text { Domain }\end{array}$ & $\begin{array}{c}\text { Urban Quality of Life } \\
\text { (UQoL) Class }\end{array}$ \\
\hline $1.475173354^{-}$ & Class 1 \\
2.139308434 & \\
$2.139308435-$ & Class 2 \\
2.843443513 & \\
$2.843443514-$ & Class 3 \\
3.527578592 & \\
\hline
\end{tabular}

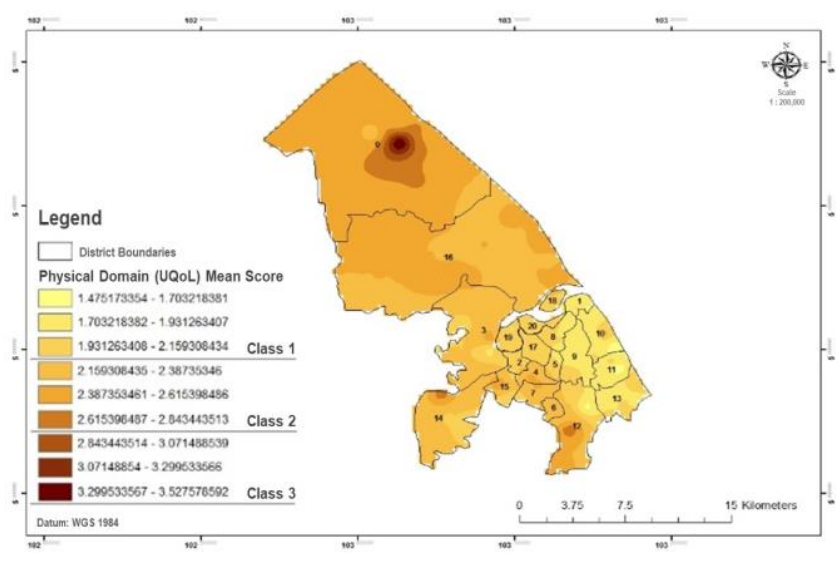

Figure 5. The Physical Domain Spatial Models and Urban Quality of Life (UQoL) Class in Kuala Terengganu, Terengganu, Malaysia

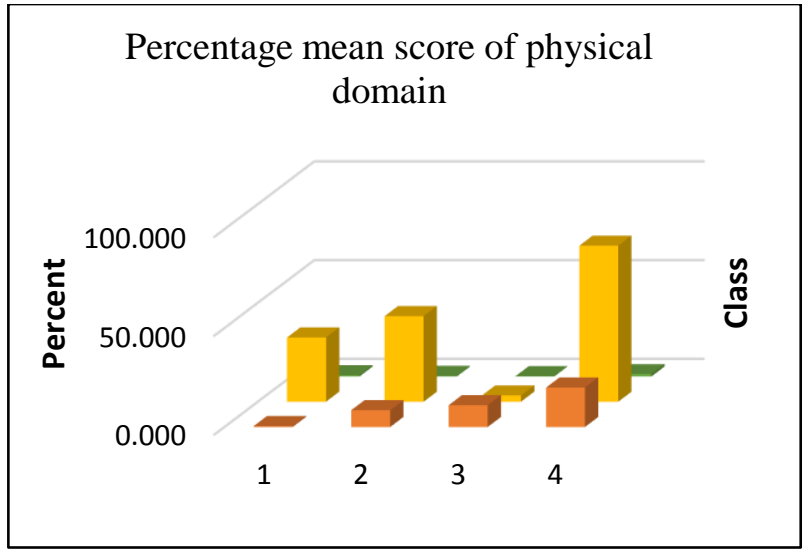

Figure 6. The percentage of mean score values of Physical Domain Spatial Models and Urban Quality of Life (UQoL)

Class in Kuala Terengganu, Terengganu, Malaysia

\section{B. Social Domain Spatial Model}

Based on Table 2 and Figure 7, the smallest mean scores of the social domain between 1.89 until 2.18 which are the areas in Class 1 . These areas covered with the 3 brightest colours which represented the areas around Batu Rakit (North of Kuala Terengganu), Kuala Nerus (Central of Kuala Terengganu) and surrounding Kuala Terengganu City Centre (South of Kuala Terengganu). Whereas, Class 2 (moderate UQoL level) with minimum mean score value between 2.18 to 2.48 which representing central areas of Kuala Terengganu around Manir, Belara and Telemong areas. Besides that, Class 3 which classified as the lowest UQoL level recorded mean score value between 2.48 until 2.79. The area is covered with 3 darkest colour levels, namely the North of Kuala Terengganu areas to Hulu Terengganu, Lake Kenyir and a few areas with the lowest population at the Pengadang Buluh and Gelugor Kedai.

Figure 8 showed the mean score values of the social domain as Class 2 which $77.61 \%$ and then Class 3 which $19.53 \%$. The lowest mean score values of the social domain as Class 1 which $2.86 \%$. The result showed the social development factors more developed in the central region compared in the south and north region of Kuala Terengganu caused by the residential development around Manir, Belara and Telemong (village). From the observation and questionnaires proved the community's activities such as the creators of associations, Gontong-Royong and management committees are successfully in Class 2 and Class 1 areas around Kuala Terengganu District. 
Table 2. The mean value of Social Domain Spatial Models and Urban Quality of Life (UQoL) Class in Kuala

Terengganu, Terengganu, Malaysia

\begin{tabular}{cc}
\hline $\begin{array}{c}\text { Mean value of Social } \\
\text { Domain }\end{array}$ & $\begin{array}{c}\text { Urban Quality of Life } \\
\text { (UQoL) Class }\end{array}$ \\
\hline $1.891515851-$ & Class 1 \\
2.187073151 & \\
$2.187073152-$ & Class 2 \\
2.482630452 & \\
$2.482630453-$ & Class 3 \\
2.778187752 & \\
\hline
\end{tabular}

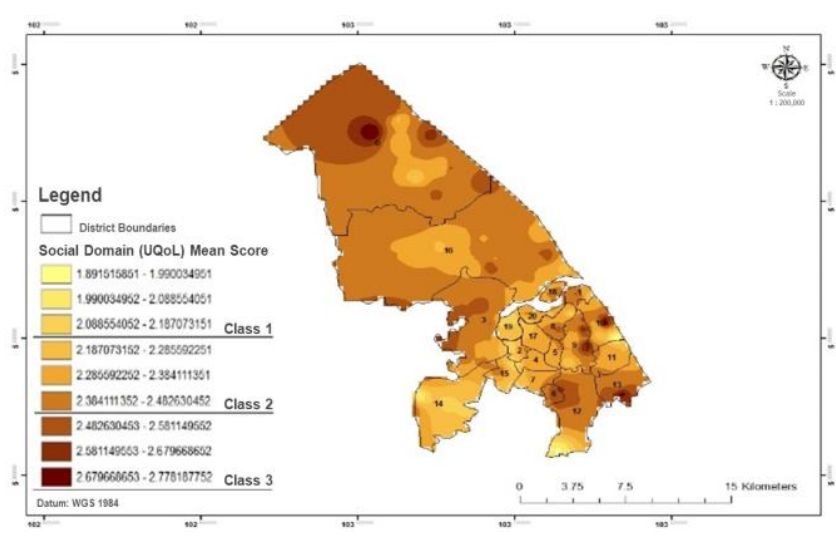

Figure 7. The Social Domain Spatial Models and Urban

Quality of Life (UQoL) Class in Kuala Terengganu,

Terengganu, Malaysia

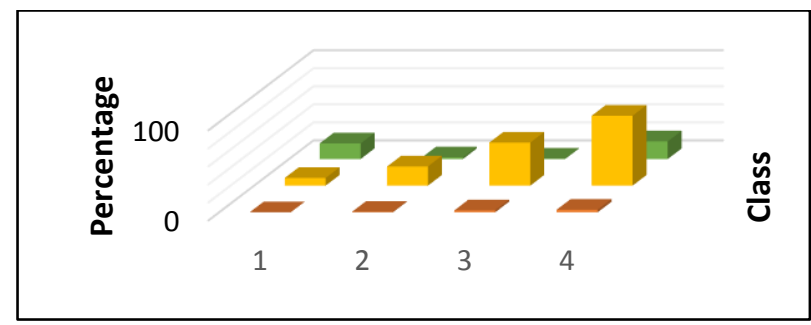

Figure 8. The percentage of mean score values of Social

Domain Spatial Models and Urban Quality of Life (UQoL)

Class in Kuala Terengganu, Terengganu, Malaysia

\section{Access Domain Spatial Model}

Based on Table 3 and Figure 9, the smallest mean scores of the access domain between 1.69 until 2.14, which are the areas in Class 1 . These areas covered with the 3 brightest colours represented the areas around Batu Rakit to Hulu Terengganu in the northern part of Kuala Terengganu District nearby the East Coast Highway 2 (LPT2) and around Kuala Ibai and Chendering areas to Dungun and Kemaman. Meanwhile, Class 2 (moderate UQoL level) with minimum mean score value between 2.13 to 2.59 which representing central areas of Kuala Terengganu around Manir, Belara and Telemong areas nearby the exit of LPT2. Also, Class 3 (lowest UQoL level) with a minimum mean score value between 2.59 to 3.03. The area is covered with the 3 darkest stages of the middle area, namely Kuala Nerus, Gong Badak and denser populated areas in Kampung Bukit Tok Beng, Kampung Tok Jembal and Serdang Baru. Based on Figure 10, the mean score values of the social domain as Class 2 which $95.01 \%$ and then Class 1 which $4.72 \%$. The lowest mean score values of the access domain as Class 1 which $0.29 \%$. The result showed the accessibility development factors more developed in the central region and northern regions compared to the south of Kuala Terengganu effected to the higher level of UQoL in the central and north of Kuala Terengganu. This is because of the more intangible way of connecting roads facilitates of the transport system in the development of road structures such as the East Coast Highway 2 (LPT2) around Terengganu which is the exit from the middle and south of Kuala Terengganu.

Table 3. The mean value of Access Domain Spatial Models and Urban Quality of Life (UQoL) Class in Kuala

Terengganu, Terengganu, Malaysia

\begin{tabular}{cc}
\hline $\begin{array}{c}\text { Mean value of Access } \\
\text { Domain }\end{array}$ & $\begin{array}{c}\text { Urban Quality of Life } \\
\text { (UQOL) Class }\end{array}$ \\
\hline $1.68859899-$ & Class 1 \\
2.137510777 & \\
$2.137510778-$ & Class 2 \\
2.586422563 & \\
$2.586422564-$ & Class 3 \\
3.035334349 & \\
\hline
\end{tabular}

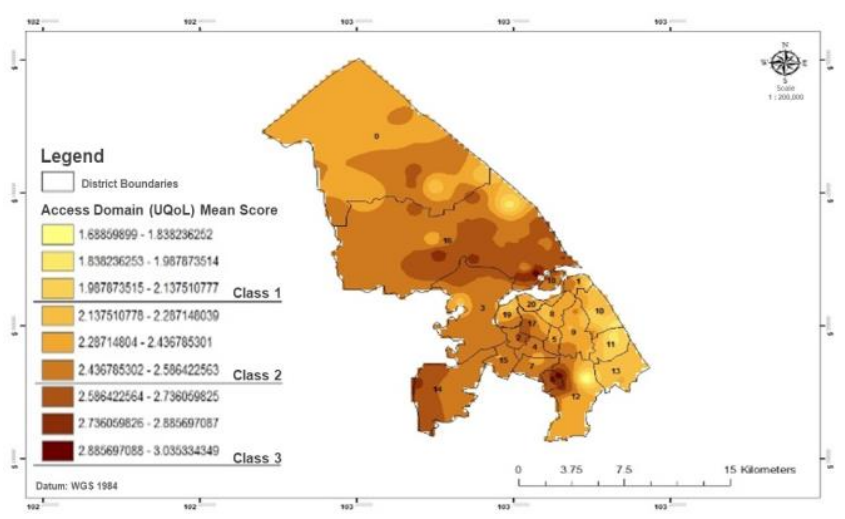

Figure 9. The Access Domain Spatial Models and UQoL

Class in Kuala Terengganu, Terengganu, Malaysia 


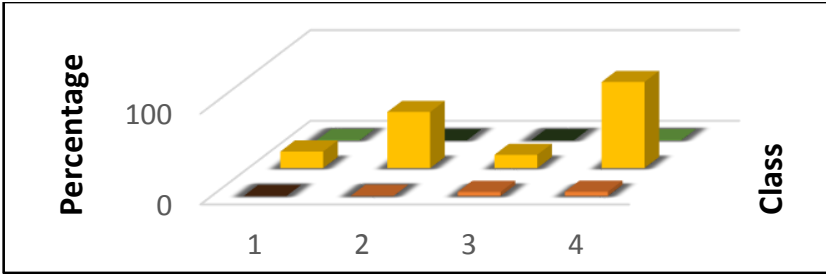

Figure 10. The percentage of mean score values of Access Domain Spatial Models and Urban Quality of Life (UQoL)

Class in Kuala Terengganu, Terengganu, Malaysia

\section{Spatial Model of Synthetic Urban Quality of Life (UQoL)}

Table 5 and Figure 11 showed the data and model spatial based on the mean scores of synthetic qualities of urban life in Kuala Terengganu. The mean score from 1.76 until 2.09 which are the areas in Class 1 (highest UQoL class). This area is covered with the 3 brightest colour tones. Whereas, Class 2 (moderate UQoL level) with a minimum mean score value between 2.09 to 2.41 , these areas covered with 3 medium colour tones. While Class 3 (low level) with minimum mean score value between 2.41 to 2.73 which covered with 3 darkest colour tones. Based on the results, most of the areas located in the northern part of Kuala Terengganu which is the areas in Class 3 (lowest UQoL level) because the area is located nearby to Hulu Terengganu and Lake Kenyir which is not well equipped with infrastructure and urbanisation process compared the southern and central areas of Kuala Terengganu located which are nearby Terengganu City Centre to Kemaman and Kertih and the Kuala Nerus and Gong Badak areas to the Besut District. Based on Figure 12, the average UQoL synthetic score is located in Class 3 which is $63.90 \%$, followed by Class 2 of $34.38 \%$ and Class 1 of $1.70 \%$.

Table 4. The mean score value of synthetic and Urban Quality of Life (UQoL) Class in Kuala Terengganu, Terengganu, Malaysia

\begin{tabular}{cc}
\hline $\begin{array}{c}\text { Mean value of the } \\
\text { synthetic score }\end{array}$ & $\begin{array}{c}\text { Urban Quality of Life } \\
\text { (UQoL) Class }\end{array}$ \\
\hline $1.763949752-$ & Class 1 \\
2.086830934 & \\
$2.086830935-$ & Class 2 \\
2.409712116 & \\
$2.409712117-$ & Class 3 \\
2.732593298 & \\
\hline
\end{tabular}

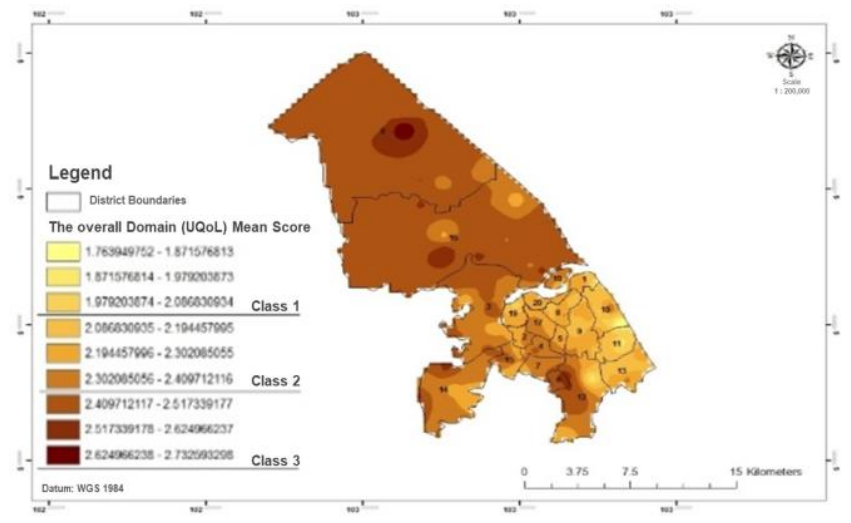

Figure 11. The overall mean scores spatial model of synthetic Urban Quality of Life (UQoL) in Kuala Terengganu, Terengganu, Malaysia

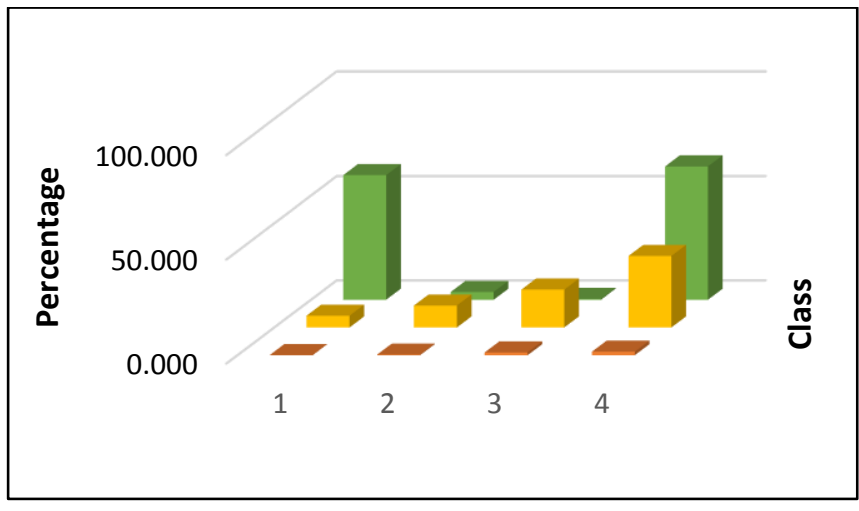

Figure 12. The percentage of mean score values of synthetic Urban Quality of Life (UQoL) Class in Kuala Terengganu,

Terengganu, Malaysia

\section{E. The Relationship Between Urbanisation Status and Urban Quality of Life (Uqol) in Kuala Terengganu}

The correlation and regression techniques with GIS have been carried out in this study to determine the urbanisation effect on UQoL status around Kuala Terengganu. Based on statistical analysis (Figure 13), the value R2 = 0.509 indicates a positive correlation relationship between two variables with weak correlation relationship. This relation showed the distance of the study area from the city centre which is the main factors of the urbanisation process in Kuala Terengganu will give a positive impact on the quality of life among communities. It's showed a $1 \%$ value of accessibility of distance of the study area from the city centre which is $50.9 \%$ of the UQoL status. Besides that, the correlation analysis showed the urbanisation process in Kuala Terengganu only 50\% correlated on the Kuala Terengganu residents' UQoL (Kamarudin et al., 2015). 


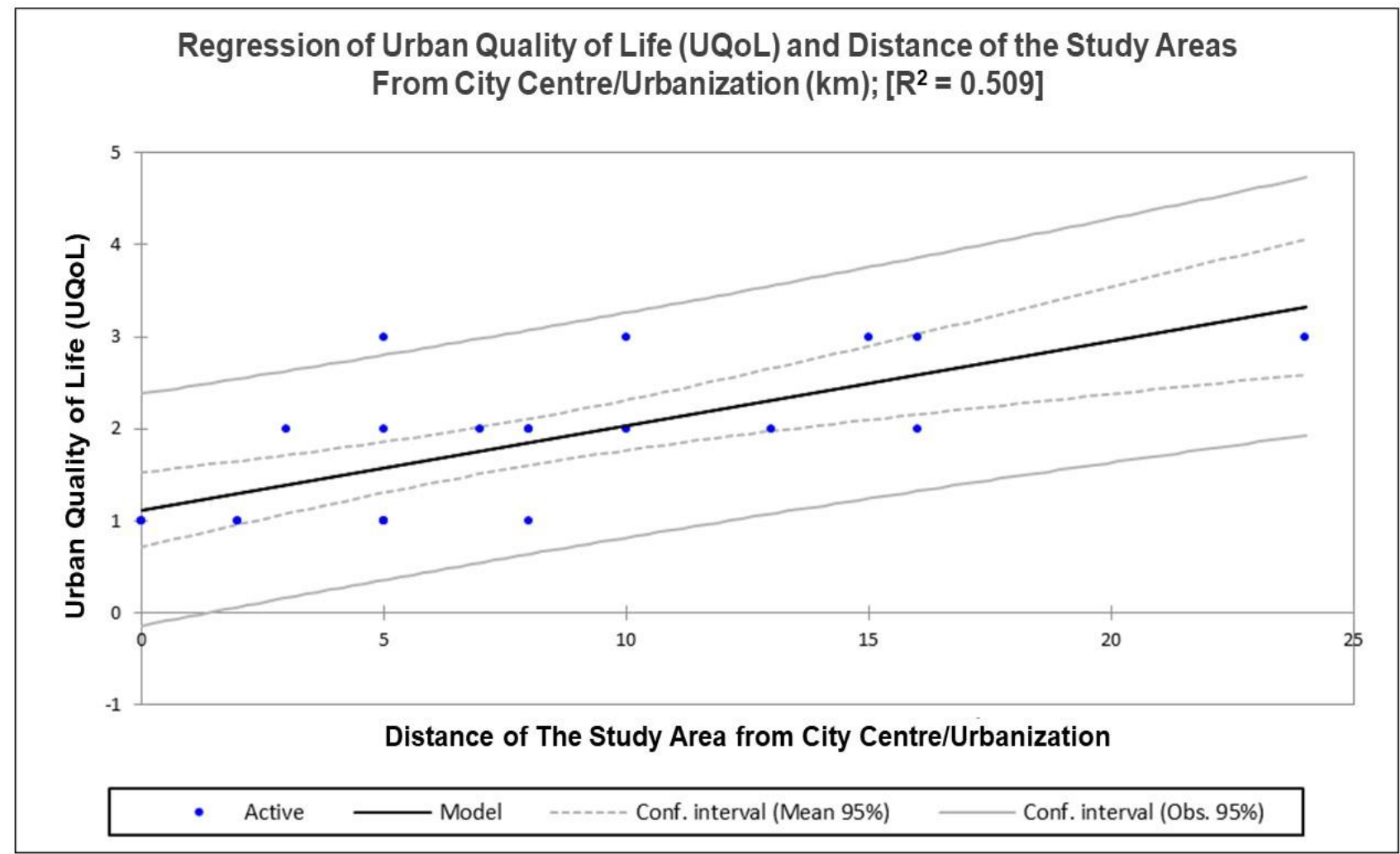

Figure 13. Regression of Urban Quality of Life (UQoL) and Distance of the study areas from city centre/urbanisation in

Kuala Terengganu, Terengganu, Malaysia

\section{CONCLUSION}

The spatial domain model can provide updated information about urbanisation status in Kuala Terengganu and communities UQoL level. This is one of the methods to measures the development rate and communities' utility level of urbanisation processes in a certain period. The resulting space model is based on spatial data sources from the year 2009 (land-use) and 2013 (satellite images) where shows that the area is in the south of Kuala Terengganu have a quality of life is better because of the proximity of the city centre and good infrastructure. The increasing of urban population and their changing needs have been met by the changing urban landscape and development level in a region especially the regions nearby with City Centre. The responsibility among communities, governance and local authorities as an important factor for the quality of life in urban communities.

\section{ACKNOWLEDGEMENTS}

The author would like to thank Kementerian Pendidikan Malaysia (KPM) for providing financial support for this research on the FRGS/1/2017/WABo5/UNISZA/01/1RR222, Department of Irrigation and Drainage Malaysia for the secondary data, East Coast Environmental Research Institute (ESERI) and Faculty of Applied and Social Sciences, Universiti Sultan Zainal Abidin (UNISZA) for the permission to use research facilities. 


\section{REFERENCES}

Arifwidodo, SD 2012, 'Exploring the effect of compact development policy to urban quality of life in Bandung, Indonesia', City, Culture and Society, vol. 3, no. 4, pp. 303311.

Azahan, A, Jamaluddin, MJ, Lukman, ZM, Kadaruddin, A and Kadir, A 2009, 'The quality of life in Malaysia's intermediate city: Urban dwellers perspective', European Journal of Social Sciences, vol. 9, no. 1, pp. 161-167.

Becker, GS, Glaeser, EL and Murphy, KM 1999, 'Population and economic growth', American Economic Review, vol. 89, no. 2, pp. 145-149.

Brueckner, JK and Largey, AG 2008, 'Social interaction and urban sprawl', Journal of Urban Economics, vol. 64, no. 1, pp. 18-34.

Buhaug, $\mathrm{H}$ and Urdal, $\mathrm{H}$ 2013, 'An urbanization bomb? Population growth and social disorder in cities', Global Environmental Change, vol. 23, no. 1, pp. 1-10.

Catalán, B, Saurí, D and Serra, P 2008, 'Urban sprawl in the Mediterranean?: Patterns of growth and change in the Barcelona Metropolitan Region 1993-2000', Landscape and urban planning, vol. 85, no. 3-4, pp. 174-184.

Cohen, B 2004, 'Urban growth in developing countries: a review of current trends and a caution regarding existing forecasts', World Development, vol. 32, no. 1, pp. 23-51.

Cohen, B 2006, 'Urbanization in developing countries: Current trends, future projections, and key challenges for sustainability', Technology in society, vol. 28, no. 1-2, pp. 6380.

Department of Statistics Malaysia 2020, viewed 1 January 2020,

https://www.dosm.gov.my/v1/index.php?r=column/ctheme \&menu_id=LopheU43NWJwRWVSZklWdzQ4TlhUUTo9\& bul_id=MDMxdHZjWTk1SjFzTzNkRXYzcVZjdzo9

Doi, K, Kii, M and Nakanishi, H 2008, 'An integrated evaluation method of accessibility, quality of life, and social interaction', Environment and Planning B: Planning and Design, vol. 35, no. 6, pp. 1098-1116.

Dredge, D 1995, 'Sustainable rapid urban expansion: the case of Xalapa, Mexico', Habitat International, vol. 19, no. 3, pp. 317-329.

Eid, J, Overman, HG, Puga, D and Turner, MA 2008, 'Fat city: Questioning the relationship between urban sprawl and obesity', Journal of Urban Economics, vol. 63, no. 2, pp. 385404.
Fahy \& Cinnéide 2008, 'Developing and Testing ANN Operational Framework for Assessing Quality of Life', Environmental Impact Assessment Review, vol. 28, pp. 366-379.

Ghurah, MHA, Kamarudin, MKA, Wahab, NA, Juahir, H, Lananan, F, Maulud, KNA, Rosli, MH, Saudi, ASM, Rizman, ZI and Zin, MSM 2018, 'Assessment of urban growth and sprawl using GIS and remote sensing techniques in South Ghor region, Al-Karak, Jordan', International Journal of Engineering and Technology (UAE), vol. 7, (3.14 Special Issue 14), pp. 5-11.

Habibi, S and Asadi, N 2011, 'Causes, results and methods of controlling urban sprawl', Procedia Engineering, vol. 21, pp. 133-141.

Hiloidhari, M, Baruah, DC, Singh, A, Kataki, S, Medhi, K, Kumari, S, Ramachandra, TV, Jenkins, BM and Thakur, IS 2017, 'Emerging role of Geographical Information System (GIS), Life Cycle Assessment (LCA) and spatial LCA (GIS-LCA) in sustainable bioenergy planning', Bioresource Technology, vol. 242, pp. 218-226.

Huang, SL, Wang, SH and Budd, WW 2009, 'Sprawl in Taipei's peri-urban zone: Responses to spatial planning and implications for adapting global environmental change', Landscape and urban planning, vol. 90, no. 1-2, pp. 20-32.

Jabatan Pembangunan Bandar Dan Desa 2008, Rancangan Tempatan Daerah Kuala Terengganu 20o8202O, JPBD.

Jabatan Perangkaan Malaysia (Cawangan Terengganu) 2014, Tidak Diterbitkan.

Kamarudin MKA, ME Toriman, MH Rosli, H Juahir, A Azid, SF Mohamed Zainuddin, NA Abdul Aziz \& WNA Sulaiman 2015, 'Analysis of Meander Evolution Studies on Effect from Land Use and Climate Change at Upstream Reach of Pahang River, Malaysia', Mitigation and Adaptation Strategies for Global Change, vol. 20, no. 8, pp. 1319-1334.

Kamarudin, MKA, Nalado, AM, Kasmuri, A, Toriman, ME, Juahir, H, Umar, R, Jamil, NR, Saudi, ASM, Rizman, ZI, Gasim, MB and Hassan, AR 2017, 'Assessment of river plan changes in Terengganu River using RS and GIS method', Journal of Fundamental and Applied Sciences, vol. 9 , no. 2 S, pp. 28-45. 
Kamarudin, MKA, Gidado, KA, Toriman, ME, Juahir, H, Umar, Sturm, R and Cohen, DA 2004, 'Suburban sprawl and

R, Wahab, NA, Ibrahim, S, Awang, S and Maulud, KNA 2018, 'Classification of land use/land cover changes using GIS and remote sensing technique in Lake Kenyir Basin, Terengganu, Malaysia', International Journal of Engineering \& Technology, vol. 7, no. 3.14, pp. 12-15.

Kamarudin, MKA, Sulaiman, NH, Wahab, NA, Toriman, ME, Hanafiah, MM, Umar, R, Hassan, AR, Rosli, MH, Samah, MAA, Harith, H 2019, 'Impact of Malaysia major flood to river geomorphology changes and Total suspended solid using GIS technique', Desalination and Water Treatment, vol. 149, pp. 242-257.

Lotfi, S, \& Koohsari, MJ 2009, 'Analyzing accessibility dimension of urban quality of life: Where urban designers face duality between subjective and objective reading of place', Social Indicators Research, vol. 94, no. 3, pp. 417-435.

Meyer, WB \& Turner, BL 1992, 'Human population growth and global land-use/cover change', Annual Review of Ecology and Systematics, vol. 23, no. 1, pp. 39-61.

Mohamad, M, Kamarudin, MKA, Juahir, H, Mat Ali, NA, Karim, F, Badarilah, N, Muhammad, N, Mohd Ridzuan, MS 2018, 'Development of Spatial Distribution Model using GIS to Identify Social Support Index among Drug-Abuse Inmates', International Journal of Engineering \& Technology, vol. 7, no. 2.15, pp. 1-7.

Pick, JB and Azari, R 2008, 'Global digital divide: Influence of socioeconomic, governmental, and accessibility factors on information technology', Information Technology for Development, vol. 14, no. 2, pp. 91-115.

Pourebrahim, S, Hadipour, M, and Mokhtar, MB 2011, 'Integration of spatial suitability analysis for land use planning in coastal areas; case of Kuala Langat District, Selangor, Malaysia', Landscape and Urban Planning, vol. 101, no. 1, pp. 84-97.

Jabatan Perancangan Bandar dan Desa Semenanjung Malaysia 2008, Rancangan Tempatan Daerah Kuala Terengganu (RTDKT: 2008-2020), Garis Architects Sda. Bhd. 2008, Percetakan Yayasan Islam Terengganu Sdn. Bhd.

Reap, J, Roman, F, Duncan, S and Bras, B 2008, 'A survey of unresolved problems in life cycle assessment', The International Journal of Life Cycle Assessment, vol. 13, no. 5, p. 374.

Shapiro, JM 2006, 'Smart cities: quality of life, productivity, and the growth effects of human capital', The Review of Economics and Statistics, vol. 88, no. 2, pp. 324-335. physical and mental health', Public Health, vol. 118, no. 7, pp. 488-496.

Travisi, CM, Camagni, R and Nijkamp, P 2010, 'Impacts of urban sprawl and commuting: a modelling study for Italy', Journal of Transport Geography, vol. 18, no. 3, pp. 382-392.

Unit Perancang Ekonomi 2010, Kualiti Hidup Malaysia 201O, Jabatan Perdana Menteri Malaysia, Kuala Lumpur, Percetakan Nasional Berhad.

Wahab, NA, Kamarudin, MKA, Anuar, A, Ata, FM, Sulaiman, NH, Baharim, NB, Harun, NS and Muhammad, NA 2017, 'Assessments of lake profiling on temperature, Total Suspended Solid (TSS) and turbidity in the Kenyir Lake, Terengganu, Malaysia', Journal of Fundamental and Applied Sciences, vol. 9, no. 2S, pp. 256-278.

Wahab, NA, Kamarudin, MKA, Toriman, ME, Juahir, H, Saad, MHM, Ata, FM, Ghazali, A, Hassan, AR, Abdullah, H, Maulud, KN, Hanafiah, MM, Harith, H 2019, 'Sedimentation and water quality deterioration problems at Terengganu River basin, Terengganu, Malaysia', Desalination and Water Treatment, vol. 149, pp. 228241.

$\mathrm{Wu}, \mathrm{F}, \mathrm{Xu}, \mathrm{J}$ and Yeh, AGO 2006, Urban development in post-reform China: state, market, and space, Routledge. Yuan, Z, Bi, J and Moriguichi, Y 2006, 'The circular economy: A new development strategy in China', Journal of Industrial Ecology, vol. 10, no. 1-2, pp. 4-8. 